\title{
Current and future state of groundwater salinization of the northern Elbe-Weser region
}

\author{
Eva González' (D) · Nico Deus ${ }^{1}$ Jörg Elbracht ${ }^{1}$ M. Azizur Rahman³ $\cdot$ Helga Wiederhold ${ }^{2}$ \\ Received: 13 August 2020 / Revised: 30 January 2021 / Accepted: 16 March 2021 / Published online: 11 November 2021 \\ (c) The Author(s) 2021
}

\begin{abstract}
Salinization of the upper aquifer of the northern Elbe-Weser region almost extends to the surface. Chloride content exceeds $250 \mathrm{mg} / \mathrm{l}$ and the groundwater is therefore, according to the German Drinking Water Ordinance, not suitable as drinking water. The chloride content in the aquifer originates from early flooding with seawater which occurred during the Holocene sea level rise. Depth and extent of the salinization were mapped by airborne electromagnetic surveys and validated by groundwater analyses. In the transition zone between the marshlands and geest areas, the fresh-saline groundwater interface falls to a depth of $>-175 \mathrm{~m}$ NHN. Due to the extensive drainage of the marshlands, seepage of fresh groundwater is impeded. Instead, an upconing of the fresh-saline groundwater interface appears due to an upwardly directed hydraulic gradient. Due to climate change, chloride concentrations will increase along the coastlines. Further inland, a decrease of chloride content in near-surface groundwater will occur.
\end{abstract}

Keywords Fresh-saline groundwater interface $\cdot \mathrm{HEM} \cdot$ Drainage $\cdot \mathrm{Cl} / \mathrm{Br}$ ratio $\cdot$ Climate change

\section{Aktuelle und zukünftige Grundwasserversalzung in der nördlichen Elbe-Weser Region}

\section{Zusammenfassung}

Der obere Grundwasserleiter der Marschen im nördlichen Elbe-Weser Gebiet ist in großen Bereichen bis wenige Meter unter Gelände mit über $250 \mathrm{mg} / \mathrm{l}$ Chlorid versalzt und damit, nach Vorgabe der deutschen Trinkwasserverordnung, als Trinkwasser nicht geeignet. Das Chlorid ist marinen Ursprungs und durch Überflutung des Gebietes im Zuge des holozänen Meeresspiegelanstiegs und nachfolgendes Versickern in den Grundwasserleiter gelangt. Tiefenlage und Verbreitung der Versalzung konnten anhand helikoptergestützter elektromagnetischer Daten detektiert, auskartiert und durch Grundwasseranalysen validiert werden. Im Geestrandbereich fällt die Süß-/Salzwassergrenze Richtung Geest ab und erreicht unterhalb der Geestkörper Tiefen von mindestens -175 m NHN. Mit der flächendeckenden Entwässerung der Marschen wird eine kontinuierliche Aussüßung des Grundwassers verhindert. Es entsteht ein nach oben gerichteter hydraulischer Gradient und dadurch eine zumindest bereichsweise fortschreitende Versalzung des oberflächennahen Grundwassers. Durch die Folgen des Klimawandels werden die Chloridkonzentrationen vor allem im Küstenbereich deutlich zunehmen, in Richtung der Geestkörper wird es hingegen zu Aussüßungserscheinungen kommen.

Schlüsselwörter Süß-/Salzwassergrenze $\cdot \mathrm{HEM} \cdot \mathrm{Cl} / \mathrm{Br}$-Verhältnis $\cdot$ Klimawandel

Eva González

eva.gonzalez@lbeg.niedersachsen.de

Nico Deus

nico.deus@lbeg.niedersachsen.de

Jörg Elbracht

joerg.elbracht@lbeg.niedersachsen.de
1 Landesamt für Bergbau, Energie und Geologie, Stilleweg 2, 30655 Hannover, Germany

2 Leibniz Institut für Angewandte Geophysik, Stilleweg 2, 30655 Hannover, Germany

3 formerly Leibniz Institut für Angewandte Geophysik, Stilleweg 2, 30655 Hannover, Germany 


\section{Introduction}

In coastal areas around the world, including Lower Saxony (northern Germany), salinization of the upper aquifer is a serious challenge for public water suppliers. In 2016, 87\% of the drinking water supply in Lower Saxony was provided from groundwater while for all of Germany, groundwater provided 69\% (www.bgr.bund.de; April 2020). This clearly stresses the importance of groundwater as a drinking water resource especially for Lower Saxony. Therefore, a consistent high quality of groundwater is important for maintaining the public water supply. It is also a challenge for the agricultural sector, even though a chloride concentration of up to $1000 \mathrm{mg} / \mathrm{l}$ is acceptable for watering (Kamphues et al. 2007). Agricultural use and habitability of the marshlands is often only guaranteed by comprehensive drainage (Müller and Müller-Späth 1965). Hence the groundwater level is kept artificially at approx. $1 \mathrm{~m} \mathrm{NHN}$ and is thus lower than its natural state. This results in an extensive upconing of salinized groundwater within the marshlands. Previous studies (e.g., Repsold 1990; Hahn 1991; Martens and Wichmann 2011; NIBIS ${ }^{\circledR}$ Kartenserver 2020f) provide a good overview of the extent of groundwater salinization of Lower Saxony's coastal aquifer system. As a result of climate change and the related sea level rise, an increase of salinization in coastal areas is to be expected. In addition to sea level rise, changing parameters in the water balance, i.e., groundwater recharge, precipitation and evaporation, and the resulting increase of drainage, also play an important role (Feseker 2007; Green et al. 2011; Rasmussen et al. 2013). To prevent deterioration of the groundwater quality, different adaptation strategies are required.

The studies shown here are part of the EU Interreg project Topsoil. The project deals not only with the problem of saltwater intrusion, but also with flooding, groundwater buffering, soil conditions and the capacity to break down nutrients. The overall aim of this project is to improve the climate resilience of the North Sea Region. The Landesamt für Bergbau, Energie and Geologie (LBEG) mapped the extent of the groundwater salinization and the depth of the fresh-saline groundwater interface (FSI) of the northern Elbe-Weser region within this project. Based on helicopterborne electromagnetic data (HEM) and groundwater analyses, a status-quo 2018 model of the FSI was determined. In addition, the future development of the FSI in the wake of climate change was simulated using different climate scenarios. Results should give an overview of the changes within the aquifer and help identify vulnerable areas with regard to drinking water supply.

\section{Project area}

The project area located between the cities of Cuxhaven, Bremerhaven, and Stade covers an area of about $1700 \mathrm{~km}^{2}$. It is bordered in the east and the north by the Elbe, in the west by the North Sea and in the south by the BremerhavenStade line. The largest river, the Oste, runs through the area for about $56 \mathrm{~km}$ and discharges into the Elbe between Otterndorf and Freiburg (Elbe). The largest lake with a surface area of $1.5 \mathrm{~km}^{2}$ is Lake Bederkesa. The area is characterised on the one hand by the low-lying marshland $( \pm 2 \mathrm{~m} \mathrm{NHN})$ with silty to clayey sediments and a dense drainage network, and on the other hand, by the elevated geest areas (up to $73 \mathrm{~m} \mathrm{NHN}$ ), made of massive glaciofluvial sand bodies and the typical "Geestrandmoore", bogs with variable extent between geest areas and marshlands. The "Generalised geological map of Lower Saxony, 1:500,000" and the geological model of the Elbe-Weser region (NIBIS Kartenserver ${ }^{\circledR}$ 2020a, b) give an overview of the near-surface geology in the project area (Fig. 1).

The Elbe-Weser region was covered by ice several times during the Elsterian and Saalian glaciations. Deep Elsterian tunnel valleys were incised and massive glaciofluvial sediment bodies were deposited (Kuster and Meyer 1979; Benda 1995; Litt et al. 2007; Ehlers et al. 2011). The northsouth directed geest bodies between Cuxhaven and Bremerhaven as well as near Lamstedt document former ice margins. The geest body near Lamstedt is characterised as a Saalian push moraine, which shows a temporary location of the ice margin during the Younger Drenthe advance (Höfle and Lade 1983; Van Gijssel 1987). The Bremerhavener-Cuxhavener Geest, is only partly characterised as a push moraine and shows the farthest extent of the Younger Drenthe advance (Meyer and Schneekloth 1973). During the Weichselian the ice advance stopped north of the Hamburg area and the Elbe-Weser region was only influenced by proglacial processes (Ehlers et al. 2011). The low-lying marshlands were flooded during the Holocene transgressions and coastal sediments with thicknesses up to $20 \mathrm{~m}$ were deposited (Streif and Köster 1978; Hoselmann and Streif 2004). Embankment and drainage of the marshlands finally stopped the natural development of the coastal zone (Streif and Köster 1978).

Due to differences of topography and geology of the geest areas and the marshlands, different hydrogeological properties also developed. Elbracht et al. (2016) assign the western part of the marshlands to the Wesermarsch and the remaining Hadelner Marsch and Kehdinger Land to the Elbmarsch (Fig. 1). Characteristic for both are brackish and marine sediments with alternating peaty and clastic materials (Streif and Köster 1978; Streif 1979; Elbracht et al. 2016). The water table elevation is between 0 and $1 \mathrm{~m} \mathrm{NHN}$ (NIBIS ${ }^{\circledR}$ Kartenserver 2020f) and groundwater recharge is 


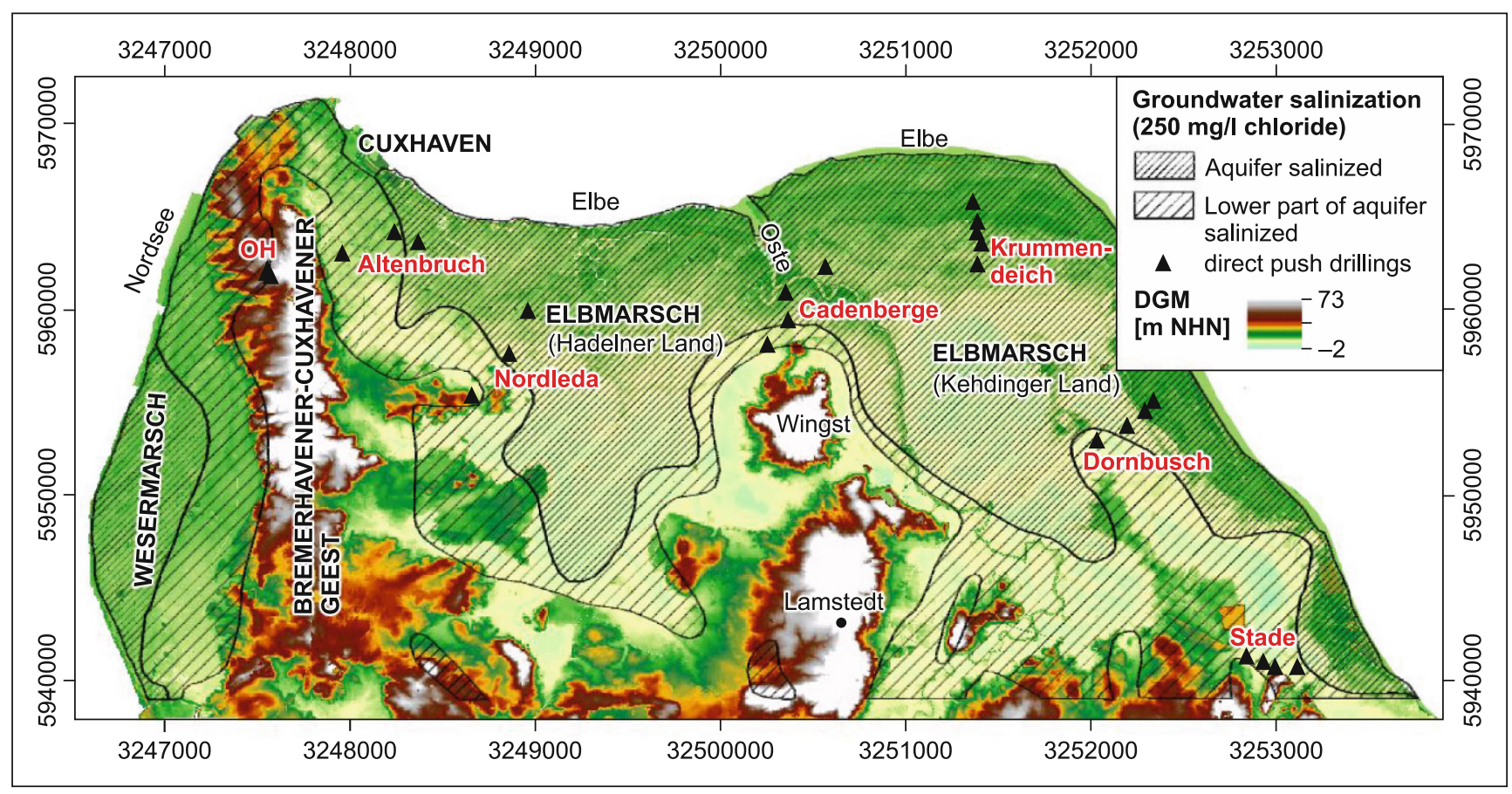

Fig. 1 Digital elevation model of the northern Elbe-Weser region with their low-lying marshlands and the higher geest areas at Wingst, Lamstedt and south of Cuxhaven. Groundwater salinization (modified after NIBIS ${ }^{\circledR}$ Kartenserver 2020g) correlates with the topography

Abb. 1 Digitales Geländemodell der nördlichen Elbe-Weser-Region, mit den tief liegenden Marschen und den höher gelegenen Geestrücken. Die Ausbreitung der Grundwasserversalzung (verändert nach NIBIS ${ }^{\circledR}$ Kartenserver 2020g) endet an den Geesträndern

$<220 \mathrm{~mm} / \mathrm{a}\left(\mathrm{NIBIS}{ }^{\circledR}\right.$ Kartenserver 2020d). The near-surface groundwater is salinized with at least $250 \mathrm{mg} / \mathrm{l}$ chloride (NIBIS ${ }^{\circledR}$ Kartenserver 2020g). The Bremerhavener-Cuxhavener Geest and the Lamstedt push moraine both belong to the Bedakesaer Geest (Elbracht et al. 2016). The water table elevation in this area is about $10 \mathrm{~m}$ NHN (NIBIS $^{\circledR}$ Kartenserver 2020f) and groundwater recharge is up to $550 \mathrm{~mm} / \mathrm{a}$ (NIBIS ${ }^{\circledR}$ Kartenserver 2020d) which is significantly higher than in the marshlands. Below the geest areas the aquifer contains freshwater (NIBIS ${ }^{\circledR}$ Kartenserver $2020 \mathrm{~g}$ ). In the entire project area, there is a multi-level aquifer system composed of Pleistocene and Pliocene sand (Elbracht et al. 2016). The upper aquifer levels consist of Elsterian and Saalian glaciofluvial sediments, while the lower level consists of tertiary sediments. Within the geest areas there are hydraulic contacts between the Elsterian tunnel valley and the Tertiary aquifers. The so called "Lauenburg clay" is the most important confining layer (Elbracht et al. 2016).

\section{Methods}

\section{Helicopter borne frequency domain electromagnetics}

For preparation of a detailed model of the fresh-saline groundwater interface, helicopter borne electromagnetic data (HEM) of the German Federal Institute for Geoscience and Natural Resources (BGR) (Siemon et al. 2013, 2017; 2019; Steuer et al. 2013) were used by González et al. (2021). These data show the distribution of the electrical resistivity $[\Omega \mathrm{m}]$ in the subsurface to a depth of $150 \mathrm{~m}$ below ground surface (Siemon et al. 2017). The resistivity distribution in the subsurface has been used to reconstruct the mineralisation of the groundwater and the clay content in the sediment (Deus and Elbracht 2015; Palacky 1986; Siemon 2005, 2006; Wiederhold et al. 2005) in combination with local geology for avoiding bias of interpretation. A detailed structural geological model of the northern ElbeWeser region was compiled previously $\left(\right.$ NIBIS $^{\circledR}$ Kartensever 2020a). Additionally, groundwater composition and borehole geophysical data were analysed to improve the model of the FSI. HEM data are also available at the BGR Geoviewer. 


\section{Direct push drillings}

Six different profiles from 18 direct push drillings within the Elbmarsch were prepared to validate the location of the FSI, modelled from HEM data (Figs. 1 and 3). The lost tip drilling method was used. Only water samples were taken, cores were not drilled. Depending on the geology and the position of the water table, the samples were taken at depths of $25 \mathrm{~m}$ below ground level to $1 \mathrm{~m}$ below ground level (if possible one sample per meter). The locations of the profiles were selected according to the expected depth of the FSI. Per profile one drilling was assumed to be within the completely salinized aquifer, one drilling within freshwater conditions and one was aimed to intersect the transition zone. The groundwater was analysed using a Dionex ion chromatograph, a Unicam UV photometer, a Spectro Arcos
ICP-OES optical spectrometer, an Agilent ICP-MS mass spectrometer and an Elementar $\mathrm{TOC} / \mathrm{TN}_{\mathrm{b}}$-Analyzer at the laboratories of the Geozentrum Hannover for the full suite of major, minor and trace constituents. The resulting chloride content $[\mathrm{mg} / \mathrm{l}]$ was used for the validation of the newly simulated FSI.

\section{Groundwater flow and transport model}

A groundwater flow and transport model of the study area, as shown in Fig. 1, was set up to study the development of the groundwater salinization in the future. A total increase of $15 \%$ from 2010 to 2100 in the amount of freshwater extraction due to the ongoing climate and demographic change was assumed and simulated with an increase of $1.7 \%$ every 10 years. Climate change was taken into ac-
Fig. 2 Recharge rates based on the RCP 8.5 scenario (IPCC 2013) for the years 2011-2040, 2041-2070 and 2071-2100 (modified after MU Niedersachsen 2019)

Abb. 2 Grundwasserneubildungsraten basierend auf dem RCP 8.5 Szenario (IPCC 2013) für die Jahre 2011-2040, 2041-2070 und 2071-2100 (verändert nach MU Niedersachsen 2019)

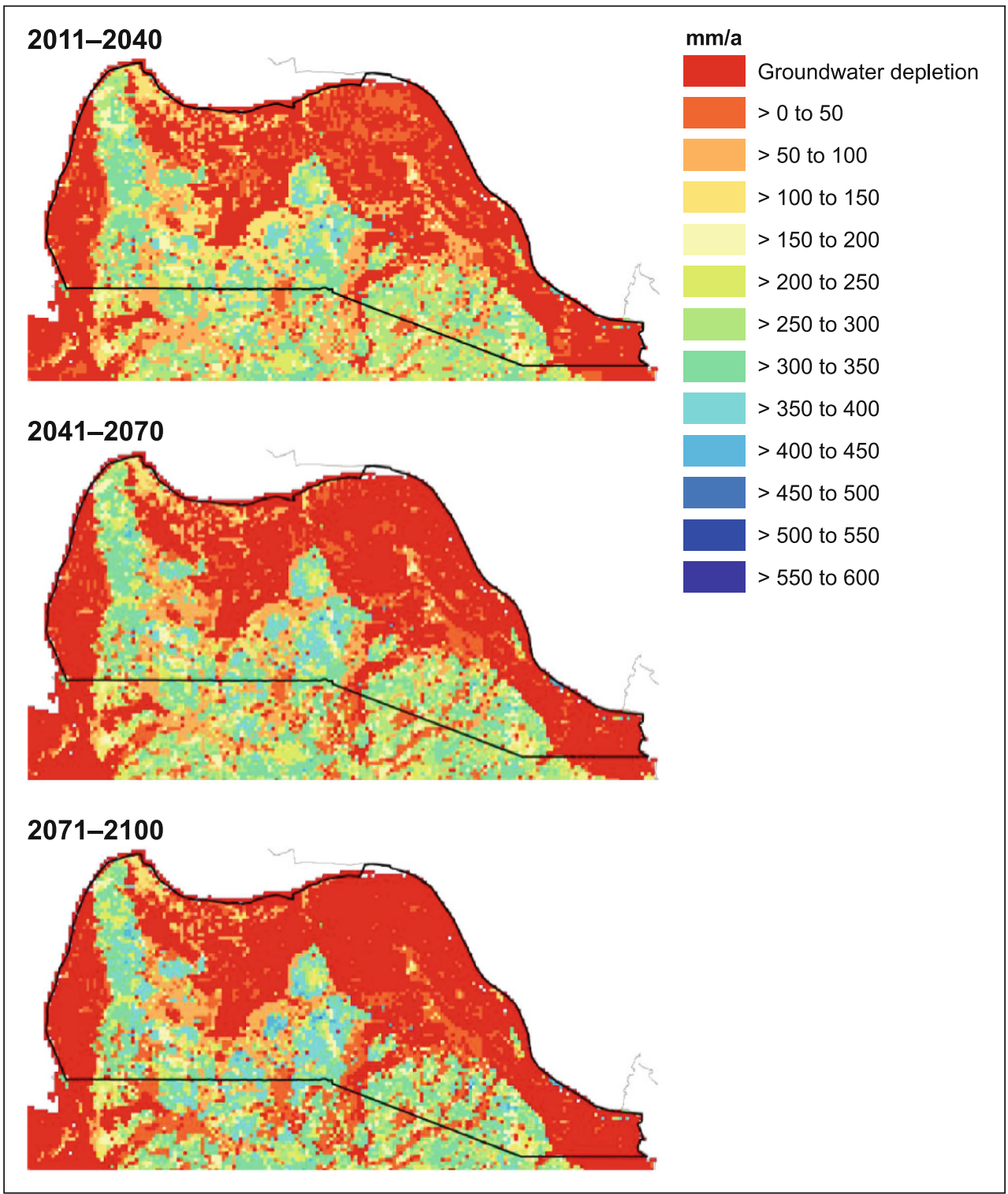


Table 1 Sea level (m NHN) from the RCP 8.5 scenario (IPCC 2013) Tab. 1 Meeresspiegel (m NHN) nach dem RCP 8.5 Szenario (IPCC 2013)

\begin{tabular}{ll}
\hline Year & Sea level (m NHN) \\
\hline 2010 & 0.04 \\
2020 & 0.08 \\
2030 & 0.13 \\
2040 & 0.19 \\
2050 & 0.25 \\
2060 & 0.33 \\
2070 & 0.42 \\
2080 & 0.51 \\
2090 & 0.62 \\
2100 & 0.74 \\
\hline
\end{tabular}

count by an average change in recharge and sea level rise according to IPCC RCP 8.5 scenario (IPCC 2013), which is the worst-case scenario of the 2013 IPCC report, with the greatest increase in temperature and greatest changes in rainfall pattern. This scenario was selected to show the greatest possible changes regarding the chloride concentration in the aquifer. Changes in rainfall pattern were incorporated into the flow model via recharge. Recharge rates (Fig. 2) based on this RCP 8.5 scenario were considered for the years 2011-2040, 2041-2070 and 2071-2100 by the water balance model mGROWA2018 (Ertl et al. 2019; MU Niedersachsen 2019), while the sea level rise was considered every 10 years (Table 1 ).

Mathematical modelling of groundwater flow was performed using the USGS-developed MODFLOW-NWT code, which is based on MODFLOW-2005 (Harbaugh 2005). At first a steady-state model was developed, followed by a transient groundwater flow and transport model that was calibrated and validated.
The model has 405 columns and 193 rows with a horizontal discretization of $200 \mathrm{~m}$ in both the $\mathrm{x}$ and $\mathrm{y}$ directions. The model domain consists of 43,448 active cells in each layer. To consider the flow, eight main layers and estimated hydrogeological parameters (e.g., conductivity, storage etc.) were identified. To maintain the spatial distribution of the geological units, the hydraulic properties of each unit were maintained where a minimum thickness exists. Therefore, if the unit was not present, a minimum thickness of $10 \mathrm{~cm}$ was assigned, but the properties of corresponding geological units were used. A minimum thickness in places were the unit is absent had to be assumed because the version of MODFLOW that was used considers continuous layers only.

Table 2 presents the initial aquifer properties (e.g., horizontal hydraulic conductivity $\left(\mathrm{K}_{\mathrm{h}}\right)$, vertical hydraulic conductivity $\left(\mathrm{K}_{\mathrm{v}}\right)$, specific storage $\left(\mathrm{S}_{\mathrm{s}}\right)$, and specific yield $\left(\mathrm{S}_{\mathrm{y}}\right)$ ) assigned to each model layer. The property values correspond to each geology type after Reutter (2011), and were fine-tuned during the calibration (Table 3) at both steady state and transient flow modelling phases. During the calibration, values for the aquifer properties were kept within its limits.

The eastern and the northern boundaries of the model (assigned with a Cauchy boundary condition) were defined by the time-varying river water stage of the Elbe River (in the model area $80.23 \mathrm{~km}$ long). The western boundary (with a Dirichlet boundary condition) was defined by the North Sea $(62.57 \mathrm{~km}$ coastline) using a constant water level of $0 \mathrm{~m}$ NHN. A groundwater level boundary (Dirichlet boundary condition) generated from monitoring wells was assigned along the southern boundary of the model. Between the monitoring wells the groundwater level was estimated using ordinary kriging interpolation. Spatially distributed

Table 2 Initial aquifer properties of each model layer (categorized according to the geology) after Reutter (2011)

Tab. 2 Aquifereigenschaften (abhängig von den geologischen Eigenschaften) der einzelnen Modell-Schichten nach Reutter (2011)

\begin{tabular}{|c|c|c|c|c|c|c|c|c|c|}
\hline \multirow[t]{2}{*}{ Layer } & \multirow[t]{2}{*}{ Geology } & \multicolumn{3}{|l|}{$\mathrm{K}_{\mathrm{h}}[\mathrm{m} / \mathrm{d}]$} & \multicolumn{3}{|l|}{$\mathrm{K}_{\mathrm{v}}[\mathrm{m} / \mathrm{d}]$} & \multirow{2}{*}{$\begin{array}{l}S_{\mathrm{X}} \\
{[1 / \mathrm{m}]}\end{array}$} & \multirow[t]{2}{*}{$\mathrm{S}_{\mathrm{y}}[-]$} \\
\hline & & Min & Avg & Max & Min & Avg & Max & & \\
\hline \multirow[t]{3}{*}{1} & Holocene peat & $8.64 e-2$ & $4.75 e-1$ & $8.64 \mathrm{e}-1$ & $1.73 e-2$ & $9.5 e-2$ & $1.73 e-1$ & $9.4 \mathrm{e}-5$ & $4.4 \mathrm{e}-1$ \\
\hline & $\begin{array}{l}\text { Brackish-marine sedi- } \\
\text { ment }\end{array}$ & $8.64 \mathrm{e}-2$ & $4.75 e-1$ & $8.64 \mathrm{e}-1$ & $1.73 e-2$ & $9.5 \mathrm{e}-2$ & $1.73 e-1$ & $9.8 \mathrm{e}-5$ & $1 e-2$ \\
\hline & $\begin{array}{l}\text { Weichselian fluviatile } \\
\text { sediment }\end{array}$ & $8.64 \mathrm{e}-1$ & $4.36 e+1$ & $8.64 \mathrm{e}+1$ & $1.73 e-1$ & 8.7 & $1.73 e+1$ & $9.87 e-6$ & $3 e-1$ \\
\hline 2 & Younger Drenthe till & $8.64 e-3$ & $4.36 \mathrm{e}-1$ & $8.64 \mathrm{e}-1$ & $1.73 e-3$ & $8.7 \mathrm{e}-2$ & $1.73 e-3$ & $5.6 e-5$ & $1.6 e-1$ \\
\hline 4 & Older Drenthe till & $8.64 e-3$ & $4.36 \mathrm{e}-1$ & $8.64 \mathrm{e}-1$ & $1.73 e-3$ & $8.7 e-2$ & $1.73 e-3$ & $5.6 e-5$ & $1.6 \mathrm{e}-1$ \\
\hline 3.5 & $\begin{array}{l}\text { Drenthe glaciofluvial } \\
\text { sediment }\end{array}$ & 8.64 & $4.75 e+1$ & $8.64 \mathrm{e}+1$ & 1.73 & 9.5 & $1.73 e+1$ & $9.87 e-6$ & $2.5 \mathrm{e}-1$ \\
\hline 6 & Lauenburg Clay & $8.64 e-5$ & $4.36 e-3$ & $8.64 e-3$ & $1.73 e-5$ & $8.7 e-4$ & $1.73 e-3$ & $9.81 \mathrm{e}-4$ & $6 e-2$ \\
\hline 7 & Elsterian till & $8.64 e-5$ & $4.36 e-3$ & $8.64 e-3$ & $1.73 e-5$ & $8.7 \mathrm{e}-4$ & $1.73 e-3$ & $9.81 \mathrm{e}-4$ & $6 e-2$ \\
\hline 8 & $\begin{array}{l}\text { Elsterian glaciofluvial } \\
\text { sediment }\end{array}$ & $8.64 e-1$ & $4.36 e+1$ & $8.64 e+1$ & $1.73 \mathrm{e}-1$ & 8.73 & $1.73 e+1$ & $9.87 e-6$ & $2.5 e-2$ \\
\hline
\end{tabular}


Table 3 Calibrated aquifer properties (horizontal hydraulic conductivity (Kh), vertical hydraulic conductivity (Kv), specific storage (Ss), and specific yield (Sy)) assigned to each model layer

Tab. 3 Kalibrierte Werte der Aquifereigenschaften (horizontale hydraulische Leitfähigkeit, vertikale hydraulische Leitfähigkeit, spezifischer Speicherkoeffizient, spezifischer Ertrag) für jede Modelleinheit

\begin{tabular}{|c|c|c|c|c|c|c|c|c|c|}
\hline \multirow[t]{2}{*}{ Layer } & \multirow[t]{2}{*}{ Geology } & \multicolumn{3}{|l|}{$\mathrm{K}_{\mathrm{h}}[\mathrm{m} / \mathrm{d}]$} & \multicolumn{3}{|l|}{$\mathrm{K}_{\mathrm{v}}[\mathrm{m} / \mathrm{d}]$} & \multirow{2}{*}{$\begin{array}{l}\mathrm{S}_{\mathrm{X}} \\
{[1 / \mathrm{m}]}\end{array}$} & \multirow[t]{2}{*}{$\mathrm{S}_{\mathrm{y}}[-]$} \\
\hline & & $\overline{M i n}$ & Avg & $\operatorname{Max}$ & $\overline{\text { Min }}$ & Avg & $\operatorname{Max}$ & & \\
\hline \multirow[t]{3}{*}{$\overline{1}$} & Holocene peat & $4.75 \mathrm{e}-1$ & $6.69 \mathrm{e}-1$ & $8.64 \mathrm{e}-1$ & $9.8 \mathrm{e}-2$ & $1.34 \mathrm{e}-1$ & $1.73 e-1$ & $9.4 e-5$ & $2 \mathrm{e}-1$ \\
\hline & $\begin{array}{l}\text { Brackish-marine } \\
\text { sediment }\end{array}$ & $8.64 \mathrm{e}-1$ & $8.64 \mathrm{e}-1$ & $8.64 e-1$ & $1.73 \mathrm{e}-1$ & $1.73 \mathrm{e}-1$ & $1.73 e-1$ & $9.8 \mathrm{e}-5$ & $1 e-1$ \\
\hline & $\begin{array}{l}\text { Weichselian fluviatile } \\
\text { sediment }\end{array}$ & $4 e+1$ & $4 e+1$ & $4 e+1$ & 8 & 8 & 8 & $9.87 e-6$ & $5 e-1$ \\
\hline 2 & Younger Drenthe till & $8.64 e-3$ & $4.36 \mathrm{e}-1$ & $8.64 \mathrm{e}-1$ & $1.73 e-3$ & $8.72 \mathrm{e}-2$ & $1.73 e-1$ & $5.6 e-5$ & $8 e-2$ \\
\hline 4 & Older Drenthe till & $4.36 \mathrm{e}-3$ & $2.2 \mathrm{e}-1$ & $4.3 e-1$ & $8.72 \mathrm{e}-4$ & $4.4 \mathrm{e}-4$ & $8.72 \mathrm{e}-2$ & $5.6 e-5$ & $5 e-2$ \\
\hline 3.5 & $\begin{array}{l}\text { Drenthe glaciofluvial } \\
\text { sediment }\end{array}$ & $1 e+1$ & $4.5 \mathrm{e}+1$ & $8 \mathrm{e}+1$ & 2 & 9 & $1.6 e+1$ & $9.87 e-6$ & $1.8 \mathrm{e}-1$ \\
\hline 6 & Lauenburg Clay & $4.36 \mathrm{e}-5$ & $2.2 \mathrm{e}-3$ & $4.36 \mathrm{e}-3$ & $8.12 \mathrm{e}-6$ & $4.4 \mathrm{e}-4$ & $8.72 \mathrm{e}-4$ & $9.81 \mathrm{e}-4$ & $5 e-2$ \\
\hline 7 & Elsterian till & $4.36 e-5$ & $2.2 \mathrm{e}-3$ & $4.36 \mathrm{e}-3$ & $8.12 \mathrm{e}-6$ & $4.4 \mathrm{e}-4$ & $8.72 e-4$ & $9.81 \mathrm{e}-4$ & $5 e-2$ \\
\hline 8 & $\begin{array}{l}\text { Elsterian glaciofluvial } \\
\text { sediment }\end{array}$ & 5 & $2.25 \mathrm{e}+1$ & $4 e+1$ & 1 & 4.5 & 8 & $9.87 e-6$ & $1.8 \mathrm{e}-2$ \\
\hline
\end{tabular}

recharge was applied along the top boundary and the model bottom was considered impermeable.

The distributed net monthly recharge was obtained from mGROWA 2018 (Ertl et al. 2019; MU Niedersachsen 2019) for the entire simulation period. Recharge was assigned directly to the water table as a prescribed flux and functions as the upper boundary of the model. The drainage condition was simulated using the drainage package of MODFLOW and was defined in two ways: the marsh drainage areas were considered as polygons and the drainage channels were considered as lines. Groundwater extraction information was obtained from six waterworks. The rivers (Elbe, Oste, and Weser) were simulated using the river package of MODFLOW.

For transport modelling, the main 8 layers were subdivided into 53 layers. The maximum thickness of each layer varied between 5 and $10 \mathrm{~m}$. The greatest thickness, with a maximum of $10 \mathrm{~m}$, was assigned at the lowest layer of the model. The aquifer properties for each sub layer were deduced from the main layers. Chloride concentration in the seawater was assigned as $16,000 \mathrm{mg} / \mathrm{l}$. The chloride concentration in the Elbe River varies between $9700 \mathrm{mg} / \mathrm{l}$ (downstream, near the North Sea) and $150 \mathrm{mg} / \mathrm{l}$ (upstream, lower right corner of the model). The chloride concentration in the Oste River varies between $100 \mathrm{mg} / \mathrm{l}$ (upstream) and $3000 \mathrm{mg} / 1$ (downstream, near the Elbe) whereas the concentration in the Weser River was set as $9700 \mathrm{mg} / \mathrm{l}$ because no data were available for that part of the Weser, which is present in the model area. The initial chloride distribution in each layer was obtained from Rahman et al. (2021). Effective porosity and dispersivity were assigned according to parameters in Table 2 . The diffusion coefficient was set to $10^{-6} \mathrm{~m}^{2} / \mathrm{d}$ (Meyer et al. 2018). The chloride concentration was calibrated against the observed chloride concentration in the year 2009.

The transient flow model was calibrated against measured groundwater levels from January 2009 to December 2013 and the validation period is January 2016. Hydraulic conductivity $\left(K_{h}\right.$ and $\left.K_{v}\right), S_{y}$ and $S_{s}$ were the calibration parameters. The transport model was calibrated against measured values of chloride from January 2009 to December 2013.

\section{Results}

\section{Present day salinity distribution based on HEM data}

Groundwater in the marshlands of the northern ElbeWeser region is nearly completely salinized, and therefore it is not suitable as a drinking water supply (NIBIS ${ }^{\circledR}$ Kartenserver 2020g). The Hydrogeological Map of Lower Saxony 1:50,000 gives a detailed overview of the depth of groundwater salinization in the project area (NIBIS ${ }^{\circledR}$ Kartenserver 2020e). The map is based on the fresh-saline groundwater interface modelled by using the HEM data (Fig. 3). The data were compiled within the Topsoil project.

In contrast to the Wesermarsch, the Hadelner Marsch and the western part of the Kehdinger Land, where the groundwater is mostly salinized up to the surface, the FSI in the eastern part of the Kehdinger Land is located deeper between -20 and $-30 \mathrm{~m}$ NHN. Towards the geest areas, the FSI dips down to depths $>-100 \mathrm{~m}$ NHN. In the southeast of the project area, near the city of Stade, there is a small upconing of the FSI. Beneath the Bederkesa Geest, the FSI could not be resolved by the HEM data due to the greater depth. Groundwater analyses show groundwater saliniza- 


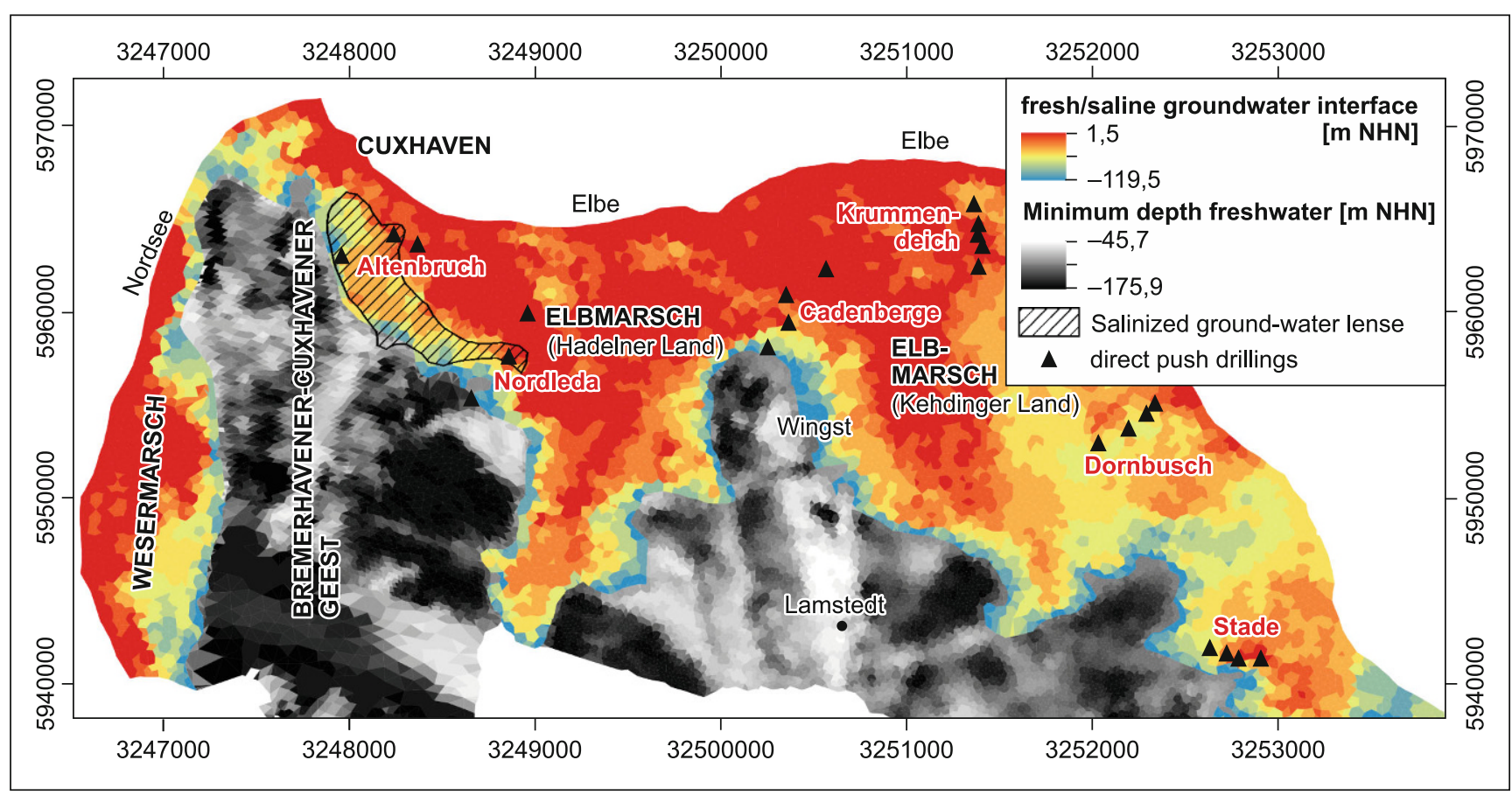

Fig. 3 Depth of the fresh-saline groundwater interface, based on the HEM data (Siemon et al. 2013, 2017, 2019; Steuer et al. 2013). The minimum depth of the freshwater below the geest area is displayed in black and grey and is derived by the maximum penetration depth of the HEM data Abb. 3 Dargestellt ist die Tiefenlage der Süß-/Salzwassergrenze, abgeleitet aus HEMDaten (Siemon et al. 2013, 2017, 2019; Steuer et al. 2013). In Graustufen ist die Mindesttiefe des Süßwassers unterhalb der Geest dargestellt, die sich aus der maximalen Eindringtiefe der HEM-Daten ergibt

tion at depths between at least $220-250 \mathrm{~m}$ below the Bremerhavener-Cuxhavener Geest and the Lamstedt area, and $-140 \mathrm{~m}$ below surface below the geest area near Stade. For the geest area, instead of the FSI, the minimum depth of freshwater was derived (González et al. 2021).

\section{Present day salinity distribution based on direct push drillings}

The depth of the FSI according to the HEM data was verified at selected locations by direct push drilling along six different transects (Fig. 4). Nordleda 3 (NL3) and Cadenberge 4 (CB4) are within the area of the geest margin, where the FSI is already very deep and where no nearsurface salinization of groundwater occurs. Stade 4 (STD4) and Dornbusch 4 (DB4) are located in the eastern part of the Elbmarsch, where the FSI is also quite deep. Freshwater conditions for all four drillings were already visible in the HEM data and were confirmed by groundwater analyses. The chloride content in the drillings Altenbruch 1 (AB1), Cadenberge 1-3 (CB1-3), Stade 1-2 (STD1-2), Dornbusch 1-3 (DB1-3) and Krummendeich 1-5 (KD1-5) increases with depth, while the total concentration of chloride varies within the marshlands. AB1, CB2 and KD1-5 intersect the FSI at different depths. All remaining drillings are located within the fully salinized groundwater. The chloride concentrations of NL3, AB2 and AB3 at depths between 15 and $20 \mathrm{~m}$ below surface are $<250 \mathrm{mg} / \mathrm{l}$ and show a freshwater lens within the salinized groundwater.

A comparison between the HEM-based FSI and the groundwater analyses shows only minor deviation and that the modelled FSI is a very good representation of the real subsurface conditions.

\section{Predicted FSI until 2100}

Model results (Fig. 5) show that there is minimal intrusion of the salinization front in the groundwater further inland. The salinization wedge between the BremerhavenerCuxhavener Geest and the Wingst will not spread further inland. In the eastern part of the project area, in the Kehdinger Land, the chloride concentration will increase between the years 2010 and 2040 at a depth of $-60 \mathrm{~m}$ NHN. In the following years, between 2040 and 2100, the concentration will decrease again. Hence, fresh water conditions will arise there again, except in the southeast corner of the area. The simulation shows that in the future and under the effects of climate change, the Geest areas will also limit the extent of salinization.

The changes in chloride concentrations with the depth, however, must be considered locally. In the area of the Wesermarsch, there is a general increase in chloride concentrations, especially in the southern part of the area. Concentrations along the river banks of the Elbe increase in 


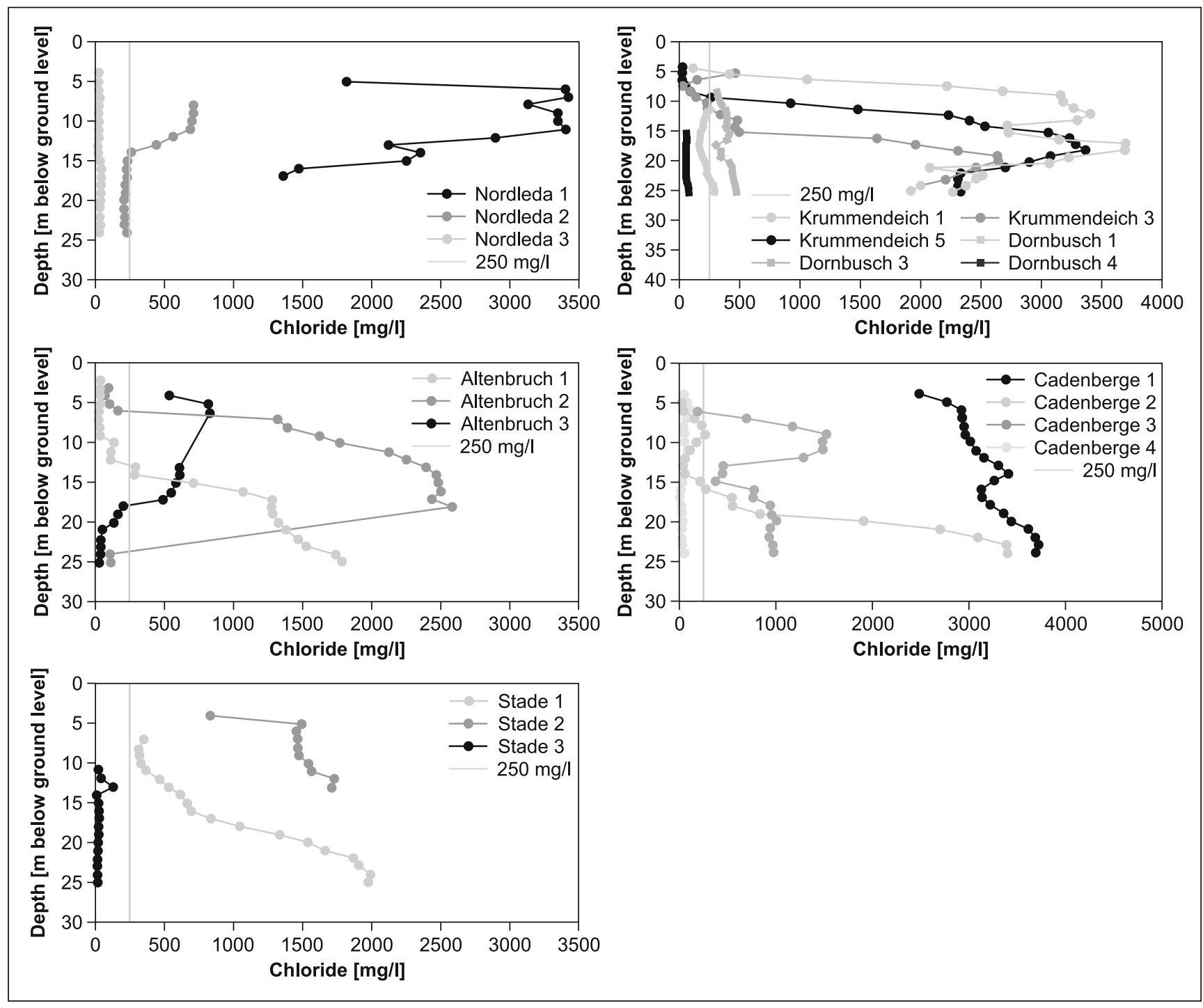

Fig. 4 Results of the groundwater analyses within the 18 direct push profiles. In the profile near Altenbruch, a salinized groundwater lens within the freshwater aquifer was detected

Abb. 4 Ergebnisse der Grundwasserproben innerhalb der 18 Direct Push Profile. In dem Profil bei Altenbruch konnte anhand der Chloridkonzentrationen eine sogenannte aufschwimmende Versalzung nachgewiesen werden

the Hadelner Marsch over time. Further inland, there is a decrease in chloride concentrations near the surface and simultaneously an increase with depth. In the Kehdinger Land area, an increase in chloride concentration between the Oste and Elbe rivers can be seen at all depths.

\section{Discussion}

The manual interpretation of the HEM data results in a detailed model of the fresh-saline groundwater interface. The FSI is modelled as a sharp interface that separates areas in the aquifer with a threshold concentration of $250 \mathrm{mg} / \mathrm{l}$ of chloride. The natural FSI, however is not a sharp static boundary but a transition zone with a thickness of several meters (Delsman et al. 2014; Eeman et al. 2011; Fetter 2001), which must be considered when using the data.

A comparison between the available groundwater analyses, e.g., direct push results and the manual interpretation of the HEM data shows high accuracy of the manual interpretation. There is only a small deviation compared to measured chloride levels, in general $<5 \mathrm{~m}$. This can be explained on the one hand by the different methods used to determine the chloride concentration, and on the other hand, due to the time intervals between data collection. The direct push profiles were created in years 2016 and 2017 and the geophysical data in years 2004 and 2008. The high accuracy of the manual method to model the FSI is also shown in a study by Siemon et al. (2018) who compared manual and automatic methods of evaluating HEM data. 


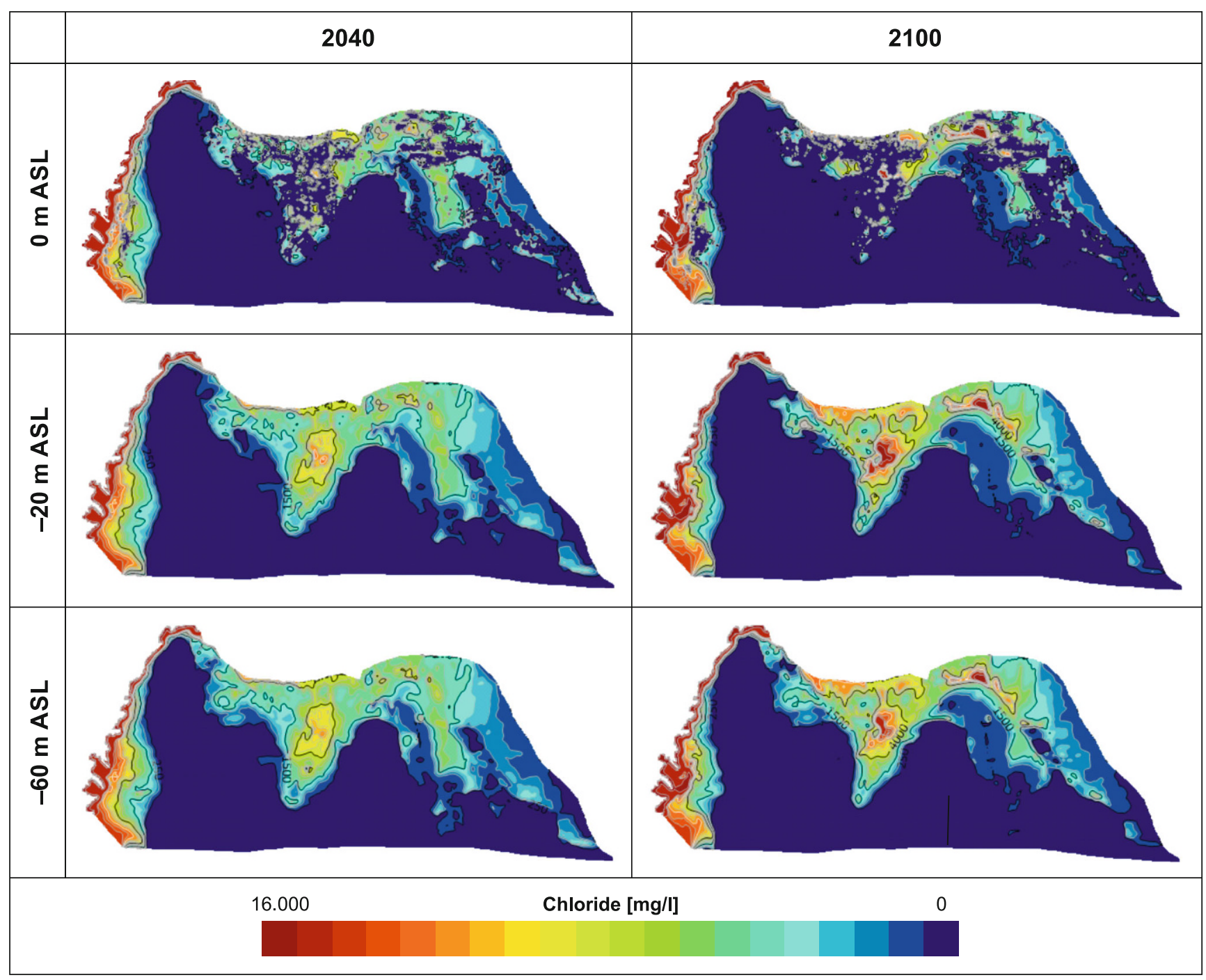

Fig. 5 Simulated spread of the salinization front in the area, as well as the chloride concentrations at different depths $(0,-20$ and $-60 \mathrm{~m} \mathrm{NHN)}$ in the years 2040 and 2100

Abb. 5 Ausbreitung der Versalzungsfront in der Fläche, sowie die Chloridkonzentrationen in unterschiedlichen Tiefenstufen $(0,-20$ und $-60 \mathrm{~m}$ NHN) in den Jahren 2040 und 2100

\section{Origin of the salinization}

The chloride/bromide ratio $[\mathrm{Cl} / \mathrm{Br}]$ gives information about the origin of chloride in groundwater (Alcalá and Custodio 2008; Davis et al. 1998; Han et al. 2011). Based on the $\mathrm{Cl} / \mathrm{Br}$ [molar ratio] and the chloride content $[\mathrm{mg} / \mathrm{l}]$ the groundwater can be assigned to different types of salinity (Alcalá and Custodio 2008). The water types which occur in the study area are classified as "Seawater origin" $(\mathrm{Cl} / \mathrm{Br}$ $\left.610-680, \mathrm{Cl}>10^{3} \mathrm{mg} / \mathrm{l}\right)$, "Leaching of natural evaporites" $\left(\mathrm{Cl} / \mathrm{Br} 1200-6600, \mathrm{Cl}>10^{4} \mathrm{mg} / \mathrm{l}\right)$, "Recharge waters" $(\mathrm{Cl} / \mathrm{Br}$ $200-1300, \mathrm{Cl}<200 \mathrm{mg} / \mathrm{l}$ ), and "anthropogenic and urban effects" $(\mathrm{Cl} / \mathrm{Br} 200-1400, \mathrm{Cl}>300 \mathrm{mg} / \mathrm{l})$, such as agricultural pollution $(\mathrm{Cl} / \mathrm{Br} 200-500)$.
The $\mathrm{Cl} / \mathrm{Br}$ ratios of most of the samples with $\mathrm{Cl}$ $>250 \mathrm{mg} / \mathrm{l}$ indicate a seawater origin with a $\mathrm{Cl} / \mathrm{Br}$ ratio around 655 (Fig. 6). With a significantly lower $\mathrm{Cl} / \mathrm{Br}$ ratio, the samples of DB1 and DB3, and also some samples from Altenbruch $(\mathrm{AB})$ and Nordleda (NL), suggest an agricultural impact on the groundwater (Alcalá and Custodio 2008), which might be explained by the agricultural land use of the Elbmarsch.

The higher $\mathrm{Cl} / \mathrm{Br}$ ratio of STD1 and STD2 and their proximity to the salt dome of Stade indicates leaching processes as the origin of the chloride content, although the signatures do not exactly match the Type "Leaching of natural evaporites" (Alcalá and Custodio 2008). Furthermore, the samples are not enriched in $\mathrm{Br}$ as, for example, samples from the Gorleben salt dome (Kloppmann et al. 2001). 
Fig. $6 \mathrm{Cl} / \mathrm{Br}$ ratios of groundwater samples taken from the direct push drillings

Abb. $6 \mathrm{Cl} / \mathrm{Br}$ der Grundwasserproben, die bei den Direct-Push Bohrungen gewonnen wurden

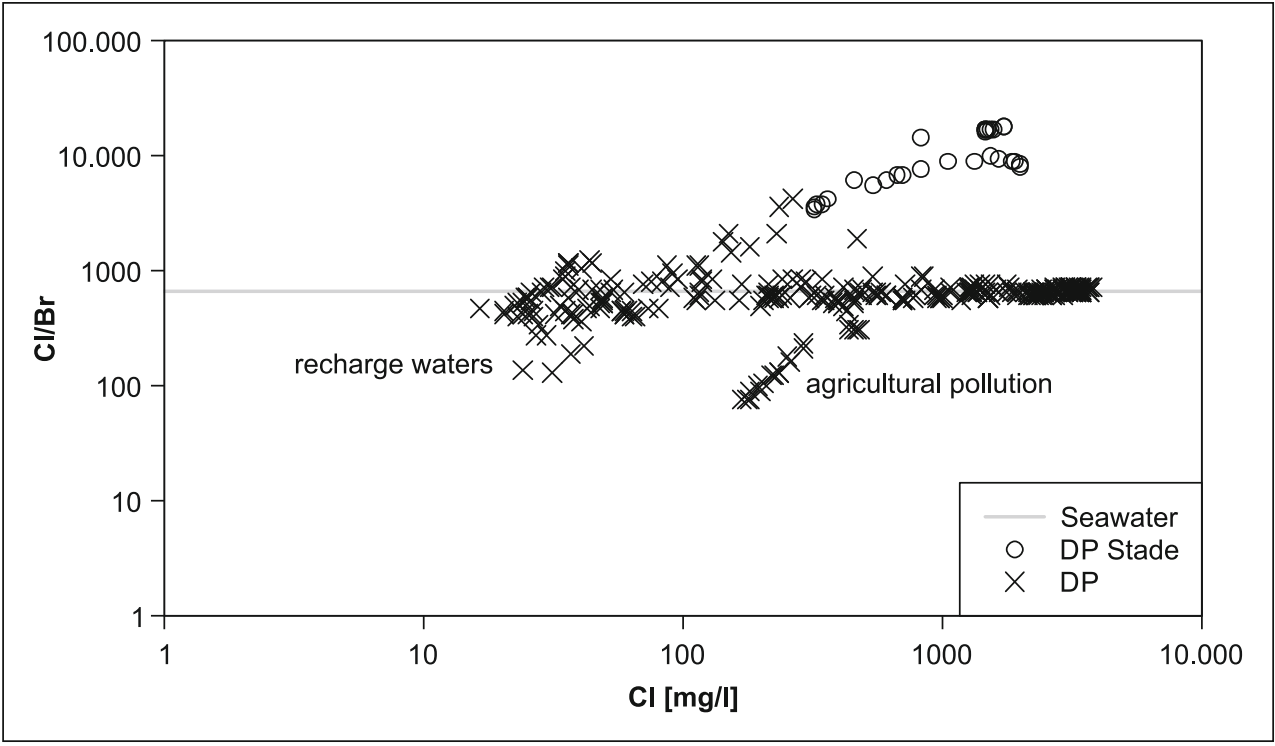

Taking into account the location of the drillings within the flooding area of former sea transgressions, it is more likely that the origin of chloride in the STD1 and STD2 samples is a mixture of seawater intrusion and leaching processes.

All samples with $\mathrm{Cl}<250 \mathrm{mg} / 1$ can be classified as "Recharge waters" (Alcalá and Custodio 2008), which is an indicator for decreasing chloride concentrations of former salinization by recharge of fresh groundwater due to precipitation.

In contrast to all other groundwater samples, the observation well Oxstedter Heide III ( -326 m NHN, LBEG data base) in the Bremerhavener-Cuxhavener Geest has relatively high bromide concentrations of $20 \mathrm{mg} / 1$. After Alcalá and Custodio (2008) the $\mathrm{Cl} / \mathrm{Br}$ signature indicates the chloride originated from leaching of natural evaporates. Hence, an origin of chloride from seawater intrusion can be excluded at this depth.

Due to the repetitive transgressions during the ongoing Holocene sea level rise, large areas of today's marshlands were frequently covered by sea water. Consequently, highly mineralised sea water seeped into the aquifer. This is also indicated by the $\mathrm{Cl} / \mathrm{Br}$ ratio of all groundwater samples within the project area, with the exception of the samples from Stade. Due to its significantly lower mineralisation and thus its lower density, recharge water floats on the underlying salinized groundwater. Under natural conditions, without drainage, the hydraulic gradient in the marshlands would be directed downwards. The FSI would therefore sink to greater depths and chloride concentrations in the aquifer would gradually decrease. However, the present-day large-scale drainage of the marshlands has induced very low groundwater recharge (Ertl et al. 2019; MU Niedersachsen 2019), so that little to no recharge water enters the aquifer and the dilution of saline water is very low. Instead, the steady drainage creates an upward hydraulic gradient, which leads to a rise of (salinized) groundwater and an upconing of the FSI (Repsold 1990; Giménez and Morell 1997; Fetter 2001).

Due to the sharp increase of chloride at depths between -15 and $-20 \mathrm{~m}$ NHN, a small decrease of chloride concentrations by groundwater recharge and related increase at greater depth over time can be assumed. In general, chloride concentrations in the groundwater of the Elbe-Weser region are below sea water concentrations $(\sim 20,000 \mathrm{mg} / \mathrm{l}$ (Millero 1974)) and therefore, indicate freshening (Jørgensen et al. 2012).

Present-day lateral extension of the salinization is linked to the Eemian Sea and the Holocene transgressions (Kooi et al. 2000), and is also documented for other coastal regions (e.g., Oude Essink et al. 2010). Due to the lower chloride concentration in the eastern part of the project area, it can be assumed that this region was less frequently flooded during Eemian and Holocene than the rest of the northern Elbe-Weser region.

South of Cuxhaven a saline lens is restricted locally to a clay lens (Fig. 3). This is shown by the results of the direct push drillings AB3, AB2 and NL2 (Fig. 4). Due to the low permeability of the marine clay (Reutter 2011) the highly mineralized water of former transgressions could not seep to greater depth and thus remains above the clay lens. The aquifer directly below is filled with freshwater, the FSI is at least a few meters lower.

\section{Comparison to previous studies}

The HÜK 200 map-Salinization of Groundwater (Fig. 4 (NIBIS ${ }^{\circledR}$ Kartenserver 2020 g) ) based on groundwater analyses, geoelectric and geophysical measurements, was pub- 


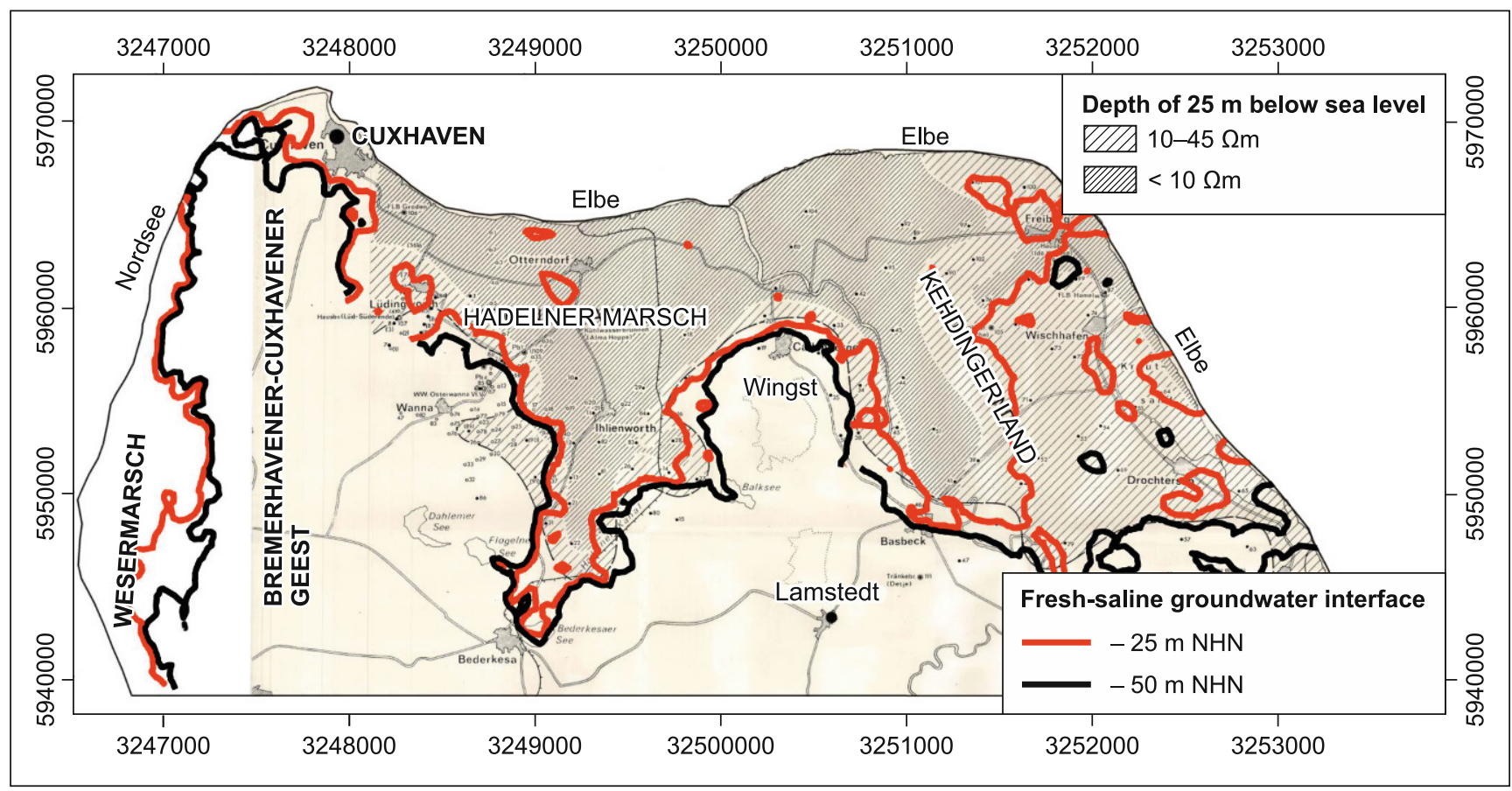

Fig. 7 Comparison of the salinity map by Repsold (1990), which shows the resistivity distribution at $25 \mathrm{~m}$ below sea level, with the new modeled FSI at $25 \mathrm{~m}$ below sea level (red line) and 50m below sea level (black line)

Abb. 7 Vergleich der Versalzungskarte von Repsold (1990), die die Widerstandsverteilung $25 \mathrm{~m}$ u NN zeigt, mit der neu modellierten Versalzungsgrenze in $25 \mathrm{~m}$ u NHN (rote Linie) und $50 \mathrm{~m}$ u NHN (schwarze Linie)

lished in 1987. The extensive groundwater salinization in the coastal zone of Lower Saxony is shown as two different types, "Aquifer completely or almost completely salinized" and "Lower Part of the Aquifer salinized". The first one is comparable with the $-25 \mathrm{~m} \mathrm{NHN}$ isoline of the newly modelled FSI and the second one with the $-50 \mathrm{~m}$ NHN isoline.

Another salinization map (Fig. 7) of the area between Cuxhaven and Stade was published by Repsold (1990). The map is also based on geoelectric measurements, which were processed with regard to the resistivity distribution in the subsurface. It shows a $45 \Omega \mathrm{m}$ isoline, which equals a chloride concentration of $250-300 \mathrm{mg} / \mathrm{l}$, and a $10 \Omega \mathrm{m}$ isoline, which indicates a chloride concentration of $1000 \mathrm{mg} / \mathrm{l}$, each at $-25 \mathrm{~m} \mathrm{NN}$. The area of resistivities $<10 \Omega \mathrm{m}$ at $-25 \mathrm{~m} \mathrm{NN}$ (Repsold, 1990) is comparable with the $-25 \mathrm{~m} \mathrm{NHN}$ isoline from the new simulated FSI. Groundwater analyses (NIBIS Labordatenbank) of the area show an average chloride concentration of $3105 \mathrm{mg} / \mathrm{l}$. In the area of the resistivity range of 10-45 $\Omega \mathrm{m}$ (Repsold, 1990), the average chloride concentration of groundwater analyses from the NIBIS Labordatenbank is $725 \mathrm{mg} / \mathrm{l}$, but the absolute concentrations vary widely. The $-25 \mathrm{~m}$ NHN isoline of the newly modelled FSI shows clearly that in 2018, salinization in the eastern part of the Elbmarsch occurs only at depths $>-25 \mathrm{~m} \mathrm{NHN}$.

A comparison with older maps (Repsold 1990; NIBIS ${ }^{\circledR}$ Kartenserver 2020g) using the Status Quo 2018 shows that the changes in extent of the salinization and depth of the FSI are very small. Due to the very low groundwater recharge and the upconing of the FSI, the expected freshening does not occur. Since today's drainage system was created around the beginning of the 20th century, an equilibrium-like stage regarding chloride concentration in the groundwater has been established, which has varied only slightly over the years. Consequently, the previously described freshening in the upper $20 \mathrm{~m}$ probably took place in earlier times, when the anthropogenic influence on the area was significantly less and the groundwater recharge was not kept artificially low by the drainage system.

\section{Development of FSI until 2100}

The simulation results of the groundwater flow and transport model predict there will be only minimum spread of the salinization front further inland until 2100 . The topography of the geest areas works as a limiting factor. Hence the nearsurface salinization remains restricted to the marshlands and saltwater intrusion beneath the geest areas is not expected. With the rising sea level and the changing groundwater recharge pattern as direct consequences of climate change, the chloride concentrations increase strongly in the areas which are already today affected by groundwater salinisation, especially in the west and the north along the North Sea coast and the Elbe. Further inland, in the Hadelner Marsch, chloride concentrations increase at greater depth 
as well. However, this is more related to freshening effects at the surface due to the higher density of the salinized groundwater than the density of freshwater and the associated vertical transport of chloride to greater depth. It is demonstrated that the situation with regard to groundwater salinisation deteriorates in the future, especially directly at the coast.

\section{Conclusion}

An accurate understanding of the geology and high-quality groundwater data for the validation of the HEM results needs to be available, since the low resistivity signatures are not only caused by high mineralization, but also by high clay contents. For example, the lens of salinized groundwater south of Cuxhaven that is separated from freshwater by the underlying clay layer could only be clearly verified with the help of groundwater analyses, since sediment and salinized groundwater have similar resistivity values there. The validation of the new modelled FSI by the HEM data using groundwater analyses shows a high level of accuracy. This confirms the chosen method to map the freshsaline interface using a threshold concentration of $250 \mathrm{mg} / \mathrm{l}$ of chloride.

A comparison with the previous work on groundwater salinity shows that the changes over the past 20 to 30 years seem to be very small. The spreading area of the saltwater wedge has not changed or has changed only slightly. However, it is questionable whether these slight deviations at $-25 \mathrm{~m} \mathrm{NHN}$ are real changes within the salt load or result from different evaluation methods (geoelectric and electromagnetic).

The groundwater flow model was designed as a largescale model which is used to get an overview and first ideas of the development of the FSI depending on climate change until the year 2100. The worst-case climate scenario RCP 8.5 has been used for this simulation. Therefore, it predicts there will be only minimal spatial spread of the salinization front until 2100. A general statement for the entire project area cannot be made regarding a possible deterioration, i.e., an increase in the chloride content. There are many isolated changes and both increases and decreases in concentrations. It is therefore recommended on the one hand to use a more detailed model that is confined to the particular area of interest for specific questions regarding the FSI. On the other hand, the simulations should also be repeated with other climate scenarios.

Acknowledgements The TOPSOIL project is co-funded by the Interreg North Sea Region Programme (J No 38246027 15). Thanks to BGR for providing the HEM data.
Funding Open Access funding enabled and organized by Projekt DEAL.

Open Access This article is licensed under a Creative Commons Attribution 4.0 International License, which permits use, sharing, adaptation, distribution and reproduction in any medium or format, as long as you give appropriate credit to the original author(s) and the source, provide a link to the Creative Commons licence, and indicate if changes were made. The images or other third party material in this article are included in the article's Creative Commons licence, unless indicated otherwise in a credit line to the material. If material is not included in the article's Creative Commons licence and your intended use is not permitted by statutory regulation or exceeds the permitted use, you will need to obtain permission directly from the copyright holder. To view a copy of this licence, visit http://creativecommons.org/licenses/by/4. $0 \%$

\section{References}

Alcalá, F.J., Custodio, E.: Using the $\mathrm{Cl} / \mathrm{Br}$ ratio as a tracer to identify the origin of salinity in aquifers in Spain and Portugal. J Hydrol 359, 189-207 (2008)

Benda, L.: Das Quartär Deutschlands. Borntraeger, Stuttgart (1995). $408 \mathrm{~S}$

Davis, S.N., Whittemore, D.O., Fabryka-Martin, J.: Uses of chloride/ bromide ratios in studies of potable water. Groundwater 36(2), 338-350 (1998)

Delsman, J.R., Hu-a-ng, K.R.M., Vos, P.C., de Louw, P.G.B., Essink, O.G.H.P., Stuyfzand, P.J., Bierkens, M.F.P.: Paleo-modeling of coastal saltwater intrusion during the Holocene: an application to the Netherlands. Hyrol. Earth Syst. Sci 18, 3891-3905 (2014)

Deus, N., Elbracht, J.: Kartierung der Grundwasserversalzung mit Hilfe geophysikalischer Befliegungsdaten im Raum Esens (Ostfriesland). GeoBerichte 32. LA f. Bergbau, Energie und Geologie, Hannover (2015). $70 \mathrm{~S}$

Eeman, S., Leijnse, A., Raats, P.A.C., Van der Zee, S.E.A.T.M.: Analysis of the thickness of a freshwater lens and of the transition zone between this lens and upwelling saline water. Adv. Water. Resour. 34(2), 191-302 (2011)

Ehlers, J., Grube, A., Stephan, H.-J., Wansa, S.: Pleistocene Glaciations of North Germany-New Results. In: Ehlers, J., Gibbard, P.L., Hughes, P.D. (eds.) Quaternary glaciations-extent and chronology: a closer look. Developments in quaternary sciences, pp. 149-162. Elsevier, Amsterdam, Boston (2011)

Elbracht, J., Meyer, R., Reutter, E.: Hydrogeologische Räume und Teilräume in Niedersachsen. GeoBerichte 3. LA f. Bergbau, Energie und Geologie, Hannover (2016). $118 \mathrm{~S}$

Ertl, G., Bug, J., Elbracht, J., Engel, N., Herrmann, F.: Grundwasserneubildung von Niedersachsen und Bremen. Berechnungen mit dem Wasserhaushaltsmodell mGROWA 18. LA $\mathrm{f}$. Bergbau, Energie und Geologie, Hannover (2019). 54 S

Fetter, C.W.: Applied Hydrogeology. Prentice Hall, Upper Saddle River (2001)

Feseker, T.: Numerical studies on saltwater intrusion in a coastal aquifer in northwestern Germany. Hydrogeol J 15, 267-279 (2007)

Giménez, E., Morell, I.: Hydrogeochemical analysis of salinization. Environ Geol 29(1/2), 118-131 (1997)

Green, T.R., Taniguchi, M., Kooi, H., Gurdak, J.J., Allen, D.M., Hiscock, K.M., Treidel, H., Aureli, A.: Beneath the surface of global change: Impacts of climate change on groundwater. J Hydrol $\mathbf{4 0 5}$, 532-560 (2011)

González, E., Deus, N., Elbracht, J., Rahman, M.A., Siemon, B., Steuer, A., Wiederhold, H.: Modellierung der küstennahen Grundwasserversalzung in Niedersachsen abgeleitet aus aeroelektro- 
magnetischen Daten. Grundwasser - Zeitschrift der Fachsektion Hydrogeologie 26, 73-85 (2021)

Hahn, J.: Grundwasser in Niedersachsen. Grundwasser Niedersachs. 7, 13-27 (1991)

Han, D., Kohfahl, C., Song, X., Xiao, G., Yang, J.: Geochemical and isotopic evidence for palaeo-seawater intrusion into the south coast aquifer of Laizhou Bay, China. Appl. Geochem. 26(5), $863-883$ (2011)

Harbaugh, A.W.: MODFLOW-2005, the US Geological Survey modular ground-water model: the ground-water flow process (pp. 6-A16). US Department of the Interior, Reston (2005). US Geological Survey

Höfle, H.-C., Lade, U.: The stratigraphic position of the Lamstedter Moraine within the Younger Drenthe substage (Middle Saalian). In: Ehlers, J. (ed.) Glacial deposits in North-West Europe, pp. 343-346. Balkema, Rotterdam (1983)

Hoselmann, C., Streif, H.: Holocene sea-level rise and its effect on the mass balance of coastal deposits. Quatern. Int. 112(1), 89-103 (2004)

IPCC: Climate change 2013: the physical science basis. Cambridge University Press, Cambridge, New York (2013). 1535 S

Jørgensen, F., Scheer, W., Thomsen, S., Sonnenborg, T.O., Hinsby, K., Wiederhold, H., Schamper, C., Burschil, T., Roth, B., Kirsch, R., Auken, E.: Transboundary geophysical mapping of geological elements and salinity distribution critical for the assessment of future sea water intrusion in response to sea level rise. Hydrol. Earth Syst. Sci. 16(7), 1845-1862 (2012). https://doi.org/10.5194/hess16-1845-2012

Kamphues, J., Böhm, R., Flachowsky, G., Lahrssen-Wiederholt, M., Meyer, U., Schenkel, H.: Empfehlungen zur Beurteilung der hygienischen Qualität von Tränkwasser für Lebensmittel liefernde Tiere unter Berücksichtigung der gegebenen rechtlichen Rahmenbedingungen. Landbauforsch. Völkenrode 57(3), 255-272 (2007)

Kloppmann, W., Négrel, P., Casanova, J., Klinge, H., Schelkes, K., Guerrot, C.: Halite dissolution derived brines in the vicinity of a Permian salt dome ( $\mathrm{N}$ German Basin). Evidence from boron, strontium, oxygen, and hydrogen isotopes. Geochim. Cosmochim. Ac. 65, 4087-4101 (2001)

Kooi, H., Groen, J., Leijnse, A.: Modes of seawater intrusion during transgressions. Water Resour. Res. 36(12), 3581-3589 (2000)

Kuster, H., Meyer, K.-D.: Glaziäre Rinnen im mittleren und nordöstlichen Niedersachsen. Eiszeitalt. U. Gegenwart 29, 135-156 (1979)

Litt, T., Behre, K.-E., Meyer, K.-D., Stephan, H.-J., Wansa, S.: Stratigraphische Begriffe für das Quartär des norddeutschen Vereisungsgebietes. Eiszeitalt. Gegenwart 56(1), 7-65 (2007)

Martens, S., Wichmann, K.: Grundwasserversorgung in Deutschland. In: Lozán, J.L.H., Graßl, P., Hupfer, L., Schönwiese, C.-D. (eds.) Warnsignal Klima: Genug Wasser für alle?, 3rd edn., pp. 203-209. (2011)

Meyer, K.-D., Schneekloth, H.: 2318 Erläuterungen zu Blatt Neuenwalde. Niedersächs. Landesamt f. Bodenforschung, Hannover, $p$ 80 (1973)

Meyer, R., Engesgaard, P., Høyer, A.S., Jørgensen, F., Vignoli, G., Sonnenborg, T.O.: Regional flow in a complex coastal aquifer system: Combining voxel geological modelling with regularized calibration. J. Hydrol. Reg. Stud. 562, 544-563 (2018)

Millero, F.J.: The physical chemistry of seawater. Annu. Rev. Eart Planet Sci 2, 101-150 (1974)

Niedersachsen, M.U.: Klimawirkungsstudie Niedersachsen. Ministerium für Umwelt, Energie, Bauen und Klimaschutz, Hannover (2019)

Müller, E., Müller-Späth, W.: Beitrag zur Entwässerung der Marsch. In: Die Küste, 13th edn., pp. 104-118. (1965)

NIBIS ${ }^{\circledR}$ Kartenserver: 3D-Modelle des Lockergesteins in Niedersachsen. Landesamt für Bergbau, Energie und Geologie, Hannover (2020a)
NIBIS ${ }^{\circledR}$ Kartenserver: Geologische Übersichtskarte von Niedersachsen 1 : 500 000. Landesamt für Bergbau, Energie und Geologie, Hannover (2020b)

NIBIS ${ }^{\circledR}$ Kartenserver: Hydrogeologische Karte von Niedersachsen 1 : 50000 - Mittlere jährliche Grundwasserneubildungsrate 1981-2010, Methode mGROWA18. Landesamt für Bergbau, Energie und Geologie, Hannover (2020d)

NIBIS ${ }^{\circledR}$ Kartenserver: Hydrogeologische Karte von Niedersachsen 1 : 50000 - Versalzung des Grundwassers. Landesamt für Bergbau, Energie und Geologie, Hannover (2020e)

NIBIS ${ }^{\circledR}$ Kartenserver: Hydrogeologische Übersichtskarte von Niedersachsen 1 : 200000 - Lage der Grundwasseroberfläche. Landesamt für Bergbau, Energie und Geologie, Hannover (2020f)

NIBIS ${ }^{\circledR}$ Kartenserver: Hydrogeologische Übersichtskarte von Niedersachsen 1:200 000 - Versalzung des Grundwassers. Landesamt für Bergbau, Energie und Geologie, Hannover (2020g)

Essink, O.G.H.P., van Baaren, E.S., de Louw, P.G.B.: Effects of climate change on coastal groundwater systems: a modelling study in the Netherlands. Water Resour. Res. 46(10), W00F04 (2010)

Palacky, G.J.: Geological background to resistivity mapping. In: Airborne resistivity mapping, pp. 19-27. (1986)

Rahman, M.A., Zhao, Q., Wiederhold, H., Skibbe, N., González, E., Deus, N., Siemon, B., Kirsch, R., Elbracht, J.: Coastal groundwater systems: mapping chloride distribution from borehole and geophysical data. Grundwasser - Zeitschrift der Fachsektion Hydrogeologie 26, 191-206 (2021)

Rasmussen, P., Sonnenborg, T.O., Goncear, G., Hinsby, K.: Assessing impacts of climate change, sea level rise, and drainage canals on saltwater intrusion to coastal aquifer. Hydrol. Earth Syst. Sci. 17, 421-443 (2013)

Repsold, H.: Geoelektrische Untersuchungen zur Bestimmung der Salz-/Süßwasser-Grenze im Gebiet zwischen Cuxhaven und Stade. Geol. Jahrb. C 56, 3-37 (1990)

Reutter, E.: Hydrostratigraphische Gliederung Niedersachsens. Geofakten 21. LA f. Bergbau, Energie und Geologie, Hannover (2011)

Siemon, B.: Ergebnisse der Aeroelektromagnetik zur Grundwassererkundung im Raum Cuxhaven-Bremerhaven. Z. Angew. Geol. 51(1), 7-13 (2005)

Siemon, B., Voß, W., Ibs-von Seht, M., Pielawa, J., Röttger, B.: Technischer Bericht Hubschrauber-Geophysik - Cuxhaven Mai 2000 (Revision 2013). Hannover. BGR-Bericht, Archiv-Nr. 0131409. (2013)

Siemon, B.: Electromagnetic methods-frequency domain: airborne techniques. In: Kirsch, R. (ed.) Groundwater geophysics: a tool for hydrogeology, pp. 155-169. Springer, Berlin, Heidelberg (2006)

Siemon, B., Steuer, A., Deus, N., Elbracht, J.: Comparison of manually and automatically derived fresh-saline groundwater boundaries from helicopter-borne EM data at the Jade Bay, Northern Germany. E3S Web Conference 54, 00032 (2018)

Siemon, B., Voß, W., Kerner, T., Pielawa, J.: Technischer Bericht Hubschraubergeophysik Hadelner Marsch Mai/Juni 2004 (Revision 2017). Hannover. BGR-Bericht, Archiv-Nr. 0134290. (2017)

Siemon, B., Ibs-von Seht, M., Pielawa, J.: Ergänzung zum Technischer Bericht - Neuauswertung der Befliegung Hadelner Marsch 2004. Hannover. BGR-Bericht, Archiv-Nr. 0135485. (2019)

Steuer, A., Siemon, B., Ibs-von Seht, M., Pielawa, J., Voß, W.: Technischer Bericht Hubschraubergeophysik - Befliegung Glückstadt, Sommer 2008 - Frühjahr 2009. Hannover. BGR-Bericht, ArchivNr. 0131097. (2013)

Streif, H.: Die Profiltypenkarte des Holozän - eine neue geologische Karte zur Darstellung von Schichtenfolgen im Küstenraum für praktische und wissenschaftliche Zwecke. Die Küste 34, 79-86 (1979)

Streif, H., Köster, R.: Zur Geologie der deutschen Nordseeküste. Die Küste 32, 30-49 (1978)

van Gijssel, K.: A lithostratigraphic and glaciotectonic reconstruction of the Lamstedt Moraine, Lower Saxony (FRG). Tills and glacio- 
tectonics: proceedings of an INQUA Symposium on Genesis and Lithology of Glacial Deposits., pp 145-155 (1987)

Wiederhold, H., Gabriel, G., Grinat, M.: Geophysikalische Erkundung der Bremerhaven-Cuxhavener Rinne im Umfeld der Forschungsbohrung Cuxhaven. Z. Angew. Geol. 51(1), 28-38 (2005)
Publisher's Note Springer Nature remains neutral with regard to jurisdictional claims in published maps and institutional affiliations. 